\title{
Blood Flow in the Forearm IN PATIENTS WITH RHEUMATOID ARTHRITIS AND HEALTHY SUBJECTS UNDER LOCAL THERMOTHERAPY
}

\begin{abstract}
Objectives: Muscle blood flow in the forearm of patients with rheumatoid arthritis and healthy volunteers following treatment with temperature increasing arm baths, mudpacks and short- or decimeter-wave diathermy was studied in this investigation. The aim of the study was to find out the difference of reactive hyperemia between the different temperature methods as well as the influence on the consensual reaction.
\end{abstract}

Subjects: Eighty patients with rheumatoid arthritis, stage 3 according to Steinbrocker, as well as 80 healthy human subjects had been assigned numerically in the four therapy-and control groups. Patients with diseases influencing the peripheral blood flow were excluded.

Design: Blood flow was measured by venous occlusion plethysmography in both forearms with the subjects lying supine. The application of the local heat therapies had been excluded on the left forearm. The forearm blood flow was monitored before heat therapy, directly after as well as in two further 10 minutes intervals. An analysis of variance was used to determine the influence on blood flow of the response to the heat therapies in patients with rheumatoid arthritis and healthy subjects.

Results: Under homogeneous starting conditions and a statistically uniformed high blood flow in rest the reactive values of blood flow on the left-hand side of application and the right consensual side showed high significant differences between all methods of therapy. Differences between the patients and the healthy subjects only showed tendencies with partially lower reactions, concerning the patients with rheumatoid arthritis. All methods of heat therapy caused a statistically provable consensual reaction that turned out smaller after diathermic methods. Here the post therapeutic reaction of the blood flow on the side of application was also lower or rather shorter.

Conclusion: Greater differences of the blood flow in rest between the patients with rheumatoid arthritis and healthy subjects could not be observed. Temperature increasing arm baths and mud packs induced a provable higher increase of local and consensual forearm blood flow than did diathermic methods. These results lead to the conclusion that there are differences in temperature distribution between the methods of therapy. Increasing arm baths and mud packs seem to have a stronger influence on the thermo reflexive skin perfusion.

\section{KEY WORDS: LOCAL HEAT THERAPY, MUSCLE BLOOD FLOW, PATIENTS WITH RHEUMATOID ARTHRITIS, HEALTHY SUBJECTS.}

\section{INTRODUCTION}

Although local heat treatment is often applied in patients with rheumatoid arthritis (RA), there are only few investigations (Mucha, 1998) on the effect of thermotherapy on peripheral blood flow. Such investigations are usually carried out in healthy subjects (Silverman and Pendleton, 1968; Wessmann, 1971). Oka et al (1971) investigated muscle blood flow in RA patients without clinical manifestations of vascular disease and observed a reduced resting blood flow with simultaneous intensification of the ischaemic reaction. Betz (1955) described a more intense warming reac- tion to temperature stimuli in patients with rheumatoid arthritis than in healthy subjects. In occasional cases, vascular lesions have also been described. Their potential role in the pathogenesis of rheumatoid arthritis has been discussed (Skrifvars et al 1969; Bowman et al 1975; Rothschild and Masi, 1982).

The following questions were to be investigated in the present study:

- What blood flow reactions result after application of various local thermotherapies (rising-temperature arm bath, parafango pack, short-wave 27,12 MHz/11m and decimeter-wave $433,92 \mathrm{MHz} / 69 \mathrm{~cm}$ treatment) on the forearm of RA patients and healthy subjects?

- What is the consensual reaction of the contralateral arm?

- What differences are present in reactive blood flow between the thermotherapies applied?

\section{CORRESPONDENCE TO:}

C Mucha

Medizinische Rehabilitation und

Prevention Deutsche Sporthochschule

Carl-Diem-Weg 6

D-50933 Köln

E-mail: mucha@dshs-koeln.de 


\section{TEST SUBJ ECTS}

Eighty patients with rheumatoid arthritis in stage 3 according to Steinbrocker (1949) and the same number of healthy test subjects were numerically allocated to eight comparison groups each comprising four treatment groups. The lack of an acute inflammatory episode, heart diseases not requiring treatment and polyneuropathies as well as normotensive blood pressure values were further inclusion criteria. In the healthy control groups, age classes and sex distribution were matched to the RA groups. All test subjects were instructed concerning the investigation procedure and method of measurement.

\section{METHODS}

The investigation took place in a laboratory with constant ambient temperature of $23-24^{\circ} \mathrm{C}$, a relative humidity of $36-38 \%$ and always at the same time of day. After an initial 20 minutes rest phase measurements and treatment took place in the supine position of the test subjects. In one patient group $(n=20)$ and a test subject group $(n=20)$ one of these thermotherapies was administered: rising-temperature arm bath, parafango wraps, short-wave diathermy, decimeter wave irradiation. The applications were carried out on the left side and for all modalities 15 minutes long.

The arm bath was carried out in a tube bath. The application started at the thermoneutral zone of $36^{\circ} \mathrm{C}$. For the next 15 minutes of application the temperature was raised successively up to $44-45^{\circ} \mathrm{C}$ adjusted by a thermostatic inflow. The parafango wrap was $4 \mathrm{~cm}$ thick and was prepared at a temperature of $55^{\circ} \mathrm{C}$. After cooling down the surface to a tolerated temperature it was applied to the entire forearm from wrist to elbow. Short-wave diathermy was applied with a diplode at dose level 4 . The Ultratherm(r) instrument (firm: Siemens) was used. For the decimeter wave irradiation the Siretherm(r) instrument (firm: Siemens) was taken. The round-field emitter was placed over the forearm at a distance of $5 \mathrm{~cm}$ at a power level of $4=80$ watts.

Forearm blood flow was measured with venous occlusion strain gauge plethysmography simultaneously on both arms before application of heat, immediately afterwards as well as 10 and 20 minutes later. Position and application conditions were maintained in accordance with the recommendations of Graf (1964). The Periquant 3800 (firm: Gutman(r)) instrument used for blood flow registration automatically evaluated the volume fluctuations and expressed them as $\mathrm{ml} / 100 \mathrm{ml}$ tissue per minute.

\section{STATISTICAL ANALYSIS}

The blood flow values obtained at the defined measurement times were recorded. After completion of the measurement series, the data were subjected to statistical analysis together with the demographic data of the test subjects as well as the anamnestic data of the patients. The statistical package of social sciences (SPSS) program system was used. For descriptive statistics, the data were broken down into initial and progress criteria and their absolute and relative incidences were compared. Multivariate analyses of variance were calculated for the group comparison over time. Univariate analyses of variance were considered in significant $\mathrm{F}$ statistics. The Newman-Keuls test was used to compare group differences. The chi-square test served as a test of homogeneity for the evaluation for qualitative

Figure 1: Forearm blood flow after application of the different methods of thermotherapy in the patient groups $(n=20)$.

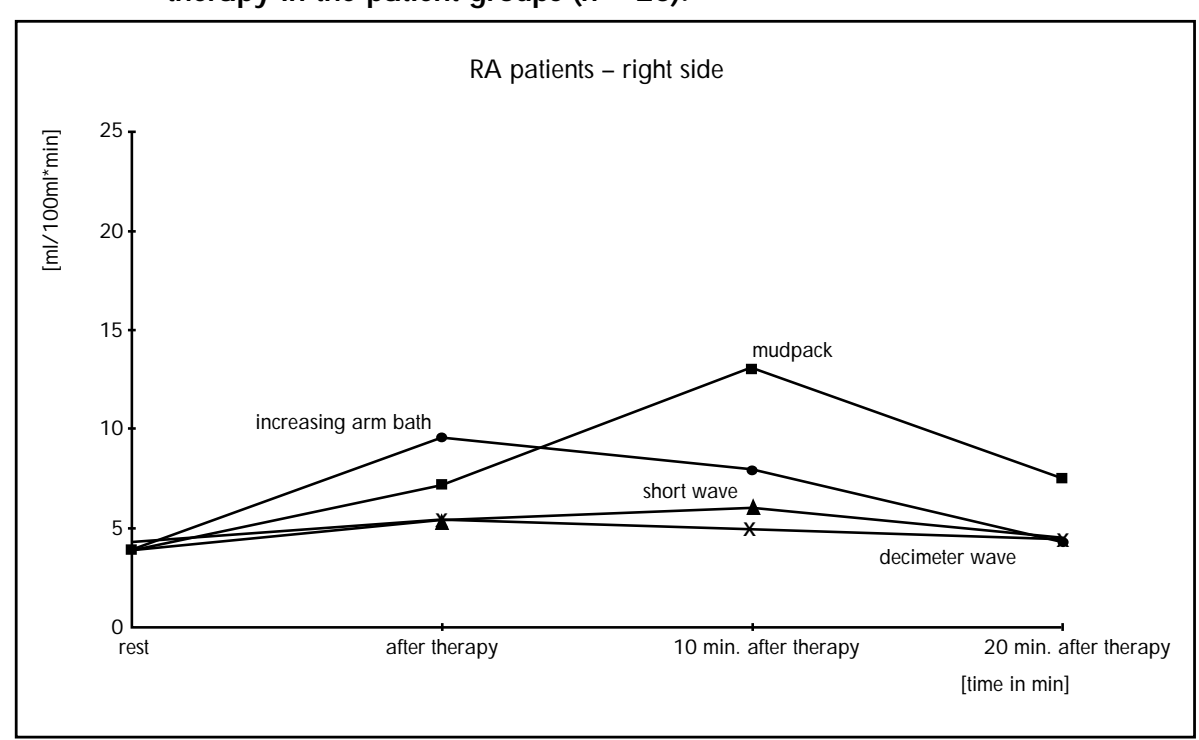

Figure 2: Forearm blood flow after application of different forms of thermotherapy in the healthy reference groups $(n=20)$.

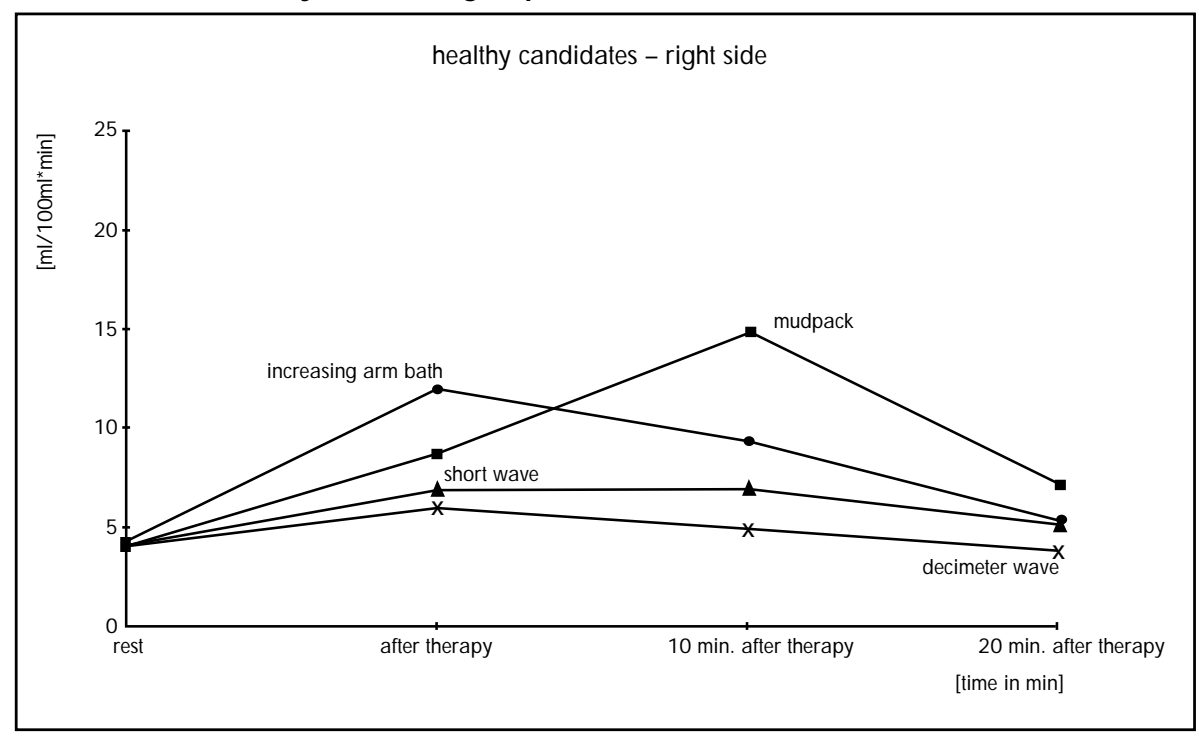


and group semiquantitative initial data in contingency tables. The t-test was used to compare two linked random samples. The probabilities of error of $5 \%(\mathrm{p}<0.05)$ and $1 \%(\mathrm{p}<0.01)$ were laid down as significant levels.

\section{RESULTS}

The age range in the overall population of the RA patients was 51 - 60 years. The average age interval of manifestation of rheumatoid arthritis was 6 - 10 years. The distribution of these features did not show any statistically significant differences in the individual groups compared. The age and sex distribution was also homogeneous between the groups of RA patients and healthy test subjects.

The blood flow values on the left (application) side in the therapy groups of RA patients and healthy test subjects at the defined measurement times are shown in Figures 1 and 2. The values of the contralateral side are shown in Figures 3 and 4 . The initial values between 3.8 and $4.3 \mathrm{ml} / 100 \mathrm{ml}$ tissue per minute in RA patients on the left and between 3.9 and $4.3 \mathrm{ml} / 100 \mathrm{ml}$ tissue per minute on the right and in healthy subjects between 3.9 and $4.3 \mathrm{ml} / 100 \mathrm{ml}$ tissue per minute on the left and 4.0 and $4.3 \mathrm{ml} / 100 \mathrm{ml}$ tissue per minute on the right, do not show any significant differences.

Figure 3: Consensual blood flow reaction in the contralateral forearm after the individual thermotherapies in the patient groups $(n=20)$.

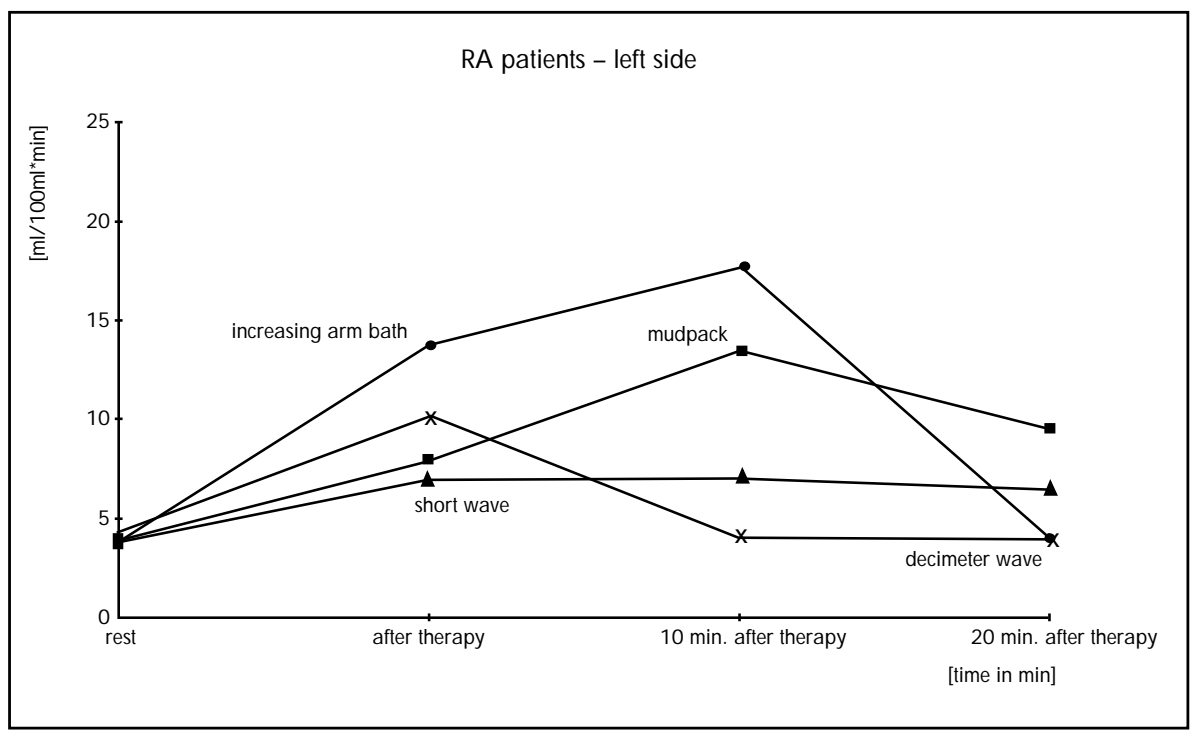

Figure 4: Consensual blood flow reaction in the contralateral forearm after the individual thermotherapies in the healthy references groups $(n=20)$.

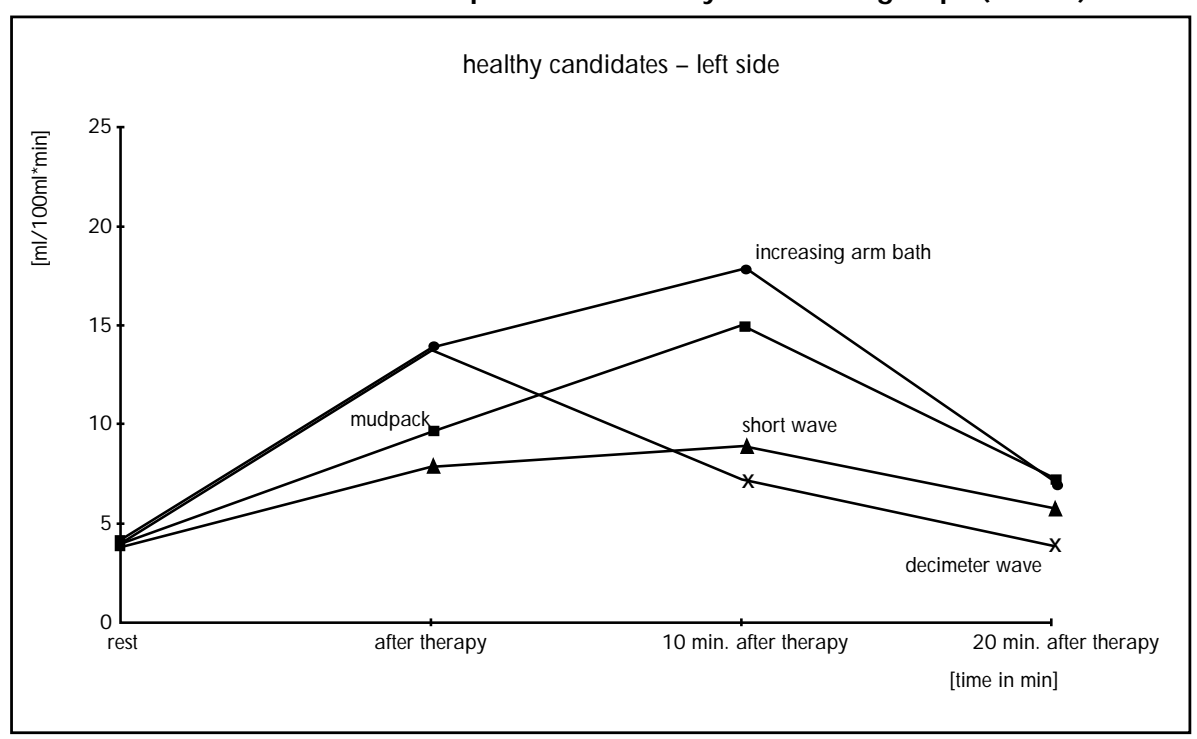

After application of thermotherapies, however, the forearm blood flow also shows a highly significant difference in the course between the methods of treatment employed $\left(\mathrm{F}_{9,682}=267.824\right.$; $\mathrm{p}=0,00)$. The post therapeutic reaction values of the blood flow between the patient and healthy subject groups are also different. This also applies to the comparison between the application side and the consensual changes in blood flow on the contralateral side $\left(\mathrm{F}_{1,54}=54.868 ; \mathrm{p}=0,00\right)$. With isolated consideration of the blood flow reactions after rising-temperature arm bath and parafango packs, these do not differ between the patient and test subject groups up to ten minutes after application. The reactive blood flow in the RA patients remains demonstrably higher than in the healthy subjects only 20 minutes after application of the parafango packs. The consensual reaction after the parafango pack also only shows slight differences compared to the application side both in the patient and in the test subject group. The blood flow reactions after application of the diathermy method (short-wave 27,12 MHz/11m and decimeter-wave 433,92 $\mathrm{MHz} / 69 \mathrm{~cm}$ ) show largely comparable interrelationships in their chronological development and in the consensual reaction. Apart from the rise in blood flow immediately after application of the decimeter wave to the left side in healthy subjects, we attained an equally high level over time to that after rising-temperature arm bath. The reaction values of both highfrequency methods are significantly lower than those after parafango packs and rising-temperature arm bath. It is noticed that after application of decimeter waves, the highest blood flow reaction was immediately after application, whereas it was only 10 minutes later in short-wave therapy. The consensual reaction is very much less with both methods and is likewise only unequivocally demonstrable immediately after application of decimeter wave treatment. Very much higher reaction values were also attained in the healthy test subjects than in the RA patients on the left (application) side. Tables 1 and 2 summarize the post therapeutic mean value comparisons between the thermo- 
therapy methods at the defined times of measurement on the application side. The corresponding values for the contralateral forearm are shown in Tables 3 and 4.

\section{DISCUSSION}

Venous occlusion plethysmography is a recognized, readily reproducible method of measurement for quantitative detection of segmental blood flow characteristics (Greenfield, 1960; Altenkirch et al 1989; Le Jemtel et al 1992).

However, the resting blood flow is especially dependent on external influences so that the test must be conducted in accordance with the recommendations by Graf (1964) in order to minimize these external influences. In this study, these recommendations include the observations of prior rest phases, positioning criteria, acclimatization, constant times of day. Resting blood flow in the forearm is reported to be between 3 and $5 \mathrm{ml} / 1001$ tissue per minute in the literature (Bollinger, 1965; Altenkirch et al 1989; Joyner et al 1990). In this investigation, it was between 3.8 and $4.3 \mathrm{ml} / 100 \mathrm{ml}$ tissue per minute. Differences between the patient and test subject groups and the lateral location were very small and could not be detected statistically. On the other hand, Oka et al (1971) found lower resting values and a more intense reactive hyperemia after ischemic stasis in RA patients compared to healthy subjects. Although they used the clearance method, the divergencies from the present results cannot necessarily be explained by the technique of measurement. It is more likely that the patient groups were not directly comparable, since Oka et al (1971) carried out the investigations in patients with manifest swelling in adjacent joints. In a further comparison, they observed that it is crucially affected by the soft-tissue conditions described. They did not observe dependence of blood flow on parameters of rheumatoid arthritis activity, duration of the disease or age of the patients. These variables were homogeneously distributed in the reference populations, so that they do not have to be taken into consideration for the cause of the reaction after local heat application. It is
Table 1: Mean value comparisons (Newman-Keuls-test) of the post therapeutic reaction of circulation on the application side within the patients' collectives.

\begin{tabular}{|c|c|c|c|c|}
\hline \multicolumn{5}{|c|}{ Immediate Post Therapy } \\
\hline Method & Short-Wave & Parafango & $\begin{array}{l}\text { Decimeter } \\
\text { Wave }\end{array}$ & $\begin{array}{l}\text { Incr. Arm } \\
\text { Bath }\end{array}$ \\
\hline 百 & 7,06 & 8,00 & 10,19 & 13,96 \\
\hline $\pm S$ & 0,99 & 1,17 & 1,16 & 1,73 \\
\hline Parafango (p) & 3,56 & $(0,05)$ & & \\
\hline Decimeter wave $(p)$ & $11,92(0,01)$ & $8,36(0,01)$ & & \\
\hline Incr. arm bath $(p)$ & $26,31(0,01)$ & $22,75(0,01)$ & $14,38(0,01)$ & \\
\hline \multicolumn{5}{|c|}{10 Minutes After Therapy } \\
\hline Method & $\begin{array}{l}\text { Decimeter } \\
\text { Wave }\end{array}$ & Short-Wave & Parafango & $\begin{array}{l}\text { Incr. Arm } \\
\text { Bath }\end{array}$ \\
\hline$\Xi$ & 5,36 & 7,36 & 13,63 & 17,95 \\
\hline $\pm S$ & 0,95 & 1,47 & 1,54 & 2,26 \\
\hline Short-wave(p) & $7,51(0,01)$ & & & \\
\hline Parafango (p) & $31,11(0,01)$ & $23,59(0,01)$ & & \\
\hline Incr. arm bath $(p)$ & $47,34(0,01)$ & $39,82(0,01)$ & $16,23(0,01)$ & \\
\hline \multicolumn{5}{|c|}{20 Minutes After Therapy } \\
\hline Method & $\begin{array}{l}\text { Decimeter } \\
\text { Wave }\end{array}$ & $\begin{array}{l}\text { Incr. Arm } \\
\text { Bath }\end{array}$ & Short-Wave & Parafango \\
\hline$\Xi$ & 4,27 & 4,35 & 6,87 & 9,80 \\
\hline $\pm S$ & 0,93 & 0,86 & 0,70 & 2,05 \\
\hline Incr. arm bath $(p)$ & 0,29 & & & \\
\hline Short-wave(p) & $9,90(0,01)$ & $9,61(0,01)$ & & \\
\hline Parafango (p) & $21,07(0,01)$ & $20,77(0,01)$ & $11,16(0,01)$ & \\
\hline
\end{tabular}

Table 2: Mean value comparisons (N ewman-Keuls-test) of the post therapeutic reaction of circulation on the application side within the healthy collectives.

\begin{tabular}{|c|c|c|c|c|}
\hline \multicolumn{5}{|c|}{ Immediate Post Therapy } \\
\hline Method & Short-Wave & Parafango & $\begin{array}{l}\text { Decimeter } \\
\text { Wave }\end{array}$ & $\begin{array}{l}\text { Incr. Arm } \\
\text { Bath }\end{array}$ \\
\hline$\Xi$ & 7,99 & 9,78 & 13,91 & 14,14 \\
\hline $\pm S$ & 1,16 & 1,15 & 1,55 & 1,71 \\
\hline Parafango (p) & $6,86(0,01)$ & & & \\
\hline Decimeter wave (p) & $22,59(0,01)$ & $15,73(0,01)$ & & \\
\hline Incr. arm bath $(p)$ & $23,45(0,01)$ & $16,59(0,01)$ & 0.85 & \\
\hline \multicolumn{5}{|c|}{10 Minutes After Therapy } \\
\hline Method & $\begin{array}{l}\text { Decimeter } \\
\text { Wave }\end{array}$ & Short-Wave & Parafango & $\begin{array}{l}\text { Incr. Arm } \\
\text { Bath }\end{array}$ \\
\hline$\Xi$ & 7,49 & 9,19 & 15,30 & 17,98 \\
\hline $\pm S$ & 1,33 & 1,43 & 1,92 & 2,13 \\
\hline Short-wave(p) & $6,47(0,01)$ & & & \\
\hline Parafango (p) & $29,74(0,01)$ & $23,26(0,01)$ & & \\
\hline Incr. arm bath (p) & $39,97(0,01)$ & $33,49(0,01)$ & $10,22(0,01)$ & \\
\hline \multicolumn{5}{|c|}{20 Minutes After Therapy } \\
\hline Method & $\begin{array}{l}\text { Decimeter } \\
\text { Wave }\end{array}$ & Short-Wave & $\begin{array}{l}\text { Incr. Arm } \\
\text { Bath }\end{array}$ & Parafango \\
\hline$\Xi$ & 4,20 & 6,02 & 7,38 & 7,51 \\
\hline $\pm S$ & 1,17 & 1,11 & 1,46 & 1,45 \\
\hline Short-wave(p) & $6,95(0,01)$ & & & \\
\hline Incr. arm bath (p) & $12,13(0,01)$ & $5,18(0,01)$ & & \\
\hline Parafango (p) & $12,63(0,01)$ & $5,67(0,01)$ & $0.49(0,01)$ & \\
\hline
\end{tabular}


Table 3: Mean value comparisons (New man-Keuls-test) of the consensual reaction of the circulation at defined control intervals within the patients' collectives.

\begin{tabular}{|c|c|c|c|c|}
\hline \multicolumn{5}{|c|}{ Immediate Post Therapy } \\
\hline Method & Short-Wave & $\begin{array}{l}\text { Decimeter } \\
\text { Wave }\end{array}$ & Parafango & $\begin{array}{l}\text { Incr. Arm } \\
\text { Bath }\end{array}$ \\
\hline$\Xi$ & 5,31 & 5,36 & 7.08 & 9.45 \\
\hline $\pm S$ & 0,97 & 0,91 & 1,00 & 1,14 \\
\hline Decimeter wave $(p)$ & 0,19 & & & \\
\hline Parafango (p) & $6,74(0,01)$ & $6,55(0,01)$ & & \\
\hline Incr. arm bath (p) & $15,77(0,01)$ & $15,58(0,01)$ & $9,03(0,01)$ & \\
\hline \multicolumn{5}{|c|}{10 Minutes After Therapy } \\
\hline Method & $\begin{array}{l}\text { Decimeter } \\
\text { Wave }\end{array}$ & Short-Wave & $\begin{array}{l}\text { Incr. Arm } \\
\text { Bath }\end{array}$ & Parafango \\
\hline$\Xi$ & 4,28 & 5,84 & 7,82 & 12,93 \\
\hline $\pm S$ & 0,95 & 1,73 & 1,21 & 1,60 \\
\hline Short-wave (p) & $6,04(0,01)$ & & & \\
\hline Incr. arm bath (p) & $13,74(0,01)$ & $7,69(0,01)$ & & \\
\hline Parafango (p) & $33,55(0,01)$ & $27,50(0,01)$ & $19,81(0,01)$ & \\
\hline \multicolumn{5}{|c|}{20 Minutes After Therapy } \\
\hline Method & $\begin{array}{l}\text { Incr. Arm } \\
\text { Bath }\end{array}$ & $\begin{array}{l}\text { Decimeter } \\
\text { Wave }\end{array}$ & Short-Wave & Parafango \\
\hline$\Xi$ & 4,04 & 4,06 & 4,27 & 8,19 \\
\hline $\pm S$ & 0,17 & 0,17 & 0,89 & 1,50 \\
\hline Decimeter wave $(p)$ & 0,07 & & & \\
\hline Short-wave (p) & 0,85 & 0,78 & & \\
\hline Parafango (p) & $15,81(0,01)$ & $15,74(0,01)$ & $14,96(0,01)$ & \\
\hline
\end{tabular}

Table 4: Mean value comparisons (New man-Keuls-test) of the consensual reaction of the circulation at defined intervals within the healthy collective.

\begin{tabular}{|c|c|c|c|c|}
\hline \multicolumn{5}{|c|}{ Immediate Post Therapy } \\
\hline Method & $\begin{array}{l}\text { Decimeter } \\
\text { Wave }\end{array}$ & Short-Wave & Parafango & $\begin{array}{l}\text { Incr. Arm } \\
\text { Bath }\end{array}$ \\
\hline$\Xi$ & 6,04 & 6,93 & 8,73 & 12,05 \\
\hline $\pm S$ & 1,15 & 1,01 & 1,27 & 1,77 \\
\hline Short-wave (p) & $3,39(0,05)$ & & & \\
\hline Parafango (p) & $10,25(0,01)$ & $6,86(0,01)$ & & \\
\hline Incr. arm bath (p) & $22,92(0,01)$ & $19,53(0,01)$ & $12,67(0,01)$ & \\
\hline \multicolumn{5}{|c|}{10 Minutes After Therapy } \\
\hline Method & $\begin{array}{l}\text { Decimeter } \\
\text { Wave }\end{array}$ & Short-Wave & $\begin{array}{l}\text { Incr. Arm } \\
\text { Bath }\end{array}$ & Parafango \\
\hline$\Xi$ & 5,12 & 7,08 & 9,45 & 14,89 \\
\hline $\pm S$ & 0,89 & 0,99 & 1,14 & 1,56 \\
\hline Short-wave (p) & $7,59(0,01)$ & & & \\
\hline Incr. arm bath (p) & $16,76(0,01)$ & $9,16(0,01)$ & & \\
\hline Parafango (p) & $37,85(0,01)$ & $30,25(0,01)$ & $21,08(0,01)$ & \\
\hline \multicolumn{5}{|c|}{20 Minutes After Therapy } \\
\hline Method & $\begin{array}{l}\text { Decimeter } \\
\text { Wave }\end{array}$ & Short-Wave & $\begin{array}{l}\text { Incr. Arm } \\
\text { Bath }\end{array}$ & Parafango \\
\hline$\Xi$ & 4,05 & 5,35 & 5,53 & 7,29 \\
\hline $\pm S$ & 0,18 & 0,94 & 1,34 & 1,31 \\
\hline Short-wave (p) & $4,97(0,01)$ & & & \\
\hline Incr. arm bath (p) & $5,64(0,01)$ & 0,66 & & \\
\hline Parafango (p) & $12,34(0,01)$ & $7,37(0,01)$ & $6,70(0,01)$ & \\
\hline
\end{tabular}

a matter of discussion as to what extent the differences in resting blood flow described by Oka et al (1971) and Bowman et al (1975) result from differences attributable to vascular disorders in RA patients. For example, Bollinger (1965) attaches no functional diagnostic importance to resting blood flow.

On the other hand, reactive hyperemia results evidently reflect the functional capacity and efficiency of the vessels after arterial stasis or after muscular exercise (Bollinger, 1965; Joyner et al 1990; Le Jemtel et al 1992). The reactive blood flow values after application of all four thermotherapies in this investigation show distinct differences from resting blood flow and in the time course of the post therapeutic control intervals. The progress differences between the forms of therapy are significant $\left(\mathrm{F}_{9,682}=267.824 ; \mathrm{p}=0,00\right)$. This applies both to the left (application) side and to the right (consensual) side. The reactive rise after rising-temperature arm bath is greater than after parafango packs, and both exceed the rises observed after diathermy techniques. The one exception is the blood flow value obtained immediately after application of decimeter wave irradiation. Moreover, the blood flow reaction persists for the shortest time and the consensual reaction is least pronounced in the case of decimeter wave irradiation. However, the raised blood flow persists for 20 minutes after application of short waves, although there is no discernible tendency to reduction in the RA patients even then, in contrast to the effect observed in the healthy test subjects. It is probable that the greater concomitant warming of the skin/subcutaneous tissue by the short wave is responsible for this effect.

Since the plethysmographic measurements simultaneously register blood flow in skin and muscle, the especially high increases in blood flow after risingtemperature arm bath and parafango packs may be due to a greatly increased blood flow in the skin. Besides intense direct warming, both forms of therapy lead to stimulation of the thermoreceptors in the skin, so that besides the direct effect of heat, an additional neuroreflex vascular reaction can be assumed 
(Peters et al 2000). This evidently led to the greater increase of blood flow. Results of Onabanjo (1978) showed that the warming of the sweat glands already leads to an enzymatically induced kininogen vasodilatation in the skin. This is moreover intensified by the effect of temperature on vasodilatory nerves. This interpretation is also supported by the vigorous consensual reaction which was attained under these forms of treatment. This fact as well as the comparatively smaller areas of application with the diathermy technique caused by technical factors could also explain their lower blood flow reactions, which would however also indicate a more direct warming of the musculature. Presupposing that there was dystrophy of the forearm musculature due to RA in patients in an advanced stage of the disease with a long period of manifestation, the greater blood flow reaction attained in the healthy patients with the diathermy technique can also be seen in this context. The characteristics of the blood flow reactions over time after application of decimeter waves also supports the assumption that it is mainly muscle blood flow which is affected in the diathermy technique, since decimeter waves lead to an even more specific warming of the musculature than short wave therapy.

According to Lehmann et al (1974) an increase in temperature to $40^{\circ} \mathrm{C}$ must be exceeded in order to attain a significant vasodilatation; moreover, this temperature must be maintained for three to five minutes. The blood values of the reactive blood flow attained in this investigation indicate that this temperature threshold was exceeded.

The influence of all four methods of treatment on the rise of forearm blood flow could be demonstrated. These results have time-course characteristics specific to the form of therapy up to 20 minutes after application. At the same time, they bring about a consensual reaction on the contralateral side. The rising-temperature arm bath and parafango packs lead to a greater increase of blood flow both on the application side and consensually than the diathermy techniques. Owing to the lack of differ- entiation between muscle and skin blood flow due to the techniques of measurement it may be assumed that their higher reaction values are brought about by a greater concomitant reaction of blood flow in the skin. The blood flow values attained after the diathermy techniques employed evidently represent mainly changes in muscle blood flow which are accompanied by a less pronounced consensual reaction. Differences between RA patients and healthy subjects could only be demonstrated in part and if anything as a tendency. Since they also represent the therapyspecific pattern of heat distribution, it may be assumed that they are a result of lower muscle volumes specific to the disease in RA patients and are less attributable to functional restrictions of the blood vessel that were referred to above all by Skrifvars et al (1969), Oka et al (1971) and Bowman et al (1975).

Of all four thermotherapies risingtemperature arm baths caused the highest rise in blood flow followed by parafango wraps and decimeter wave irradiation. A comparably small rise in blood flow was registered after shortwave application. After both short wave therapy and parafango wraps the increase of blood flow was still detectable even 20 minutes after therapy though. This indicates a longer distribution of heat after those thermotherapies. The greatest consensual reaction was caused by the rising-temperature arm bath immediately afterwards. Parafango wraps showed the greatest consensual reaction ten minutes later. No significant consensual reaction was recorded for decimeter wave irradiation. Consequently decimeter wave diathermy causes selective muscular warming.

\section{REFERENCES}

Altenkirch H-U, Fransson L, Koch G 1989: Assessment of arterial and venous circulation in upper and lower extremities by venous occlusion strain gauge plethysmography. Normal values and reproducibility. Journal of Vascular Diseases 18: 140-144

Betz E 1955 Die Störung der peripheren Durchblutung beim chronischen Rheumatismus und deren Beeinflussung durch balneotherapeutische Maflnahmen. Archiv für Physikalische Therapie $7: 141-145$
Bollinger A 1965 Bedeutung der Venenverschlussplethysmographie in der angiologischen Diagnostik. Schweizerische Medizinische Wochenschrift 95 : 1357-1362

Bowman S C, Turner R, Green H D 1975 Peripheral vascular disease in rheumatoid arthritis. Arthritis and Rheumatism 18 : 389

Graf K 1964 Auswertung und Messfehler okklusionsplethysmographischer Durchblutungsregistrierungen. Acta Physiologica Scandinavica $60: 120-135$

Greenfield A D M 1960 Venous occlusion plethysmography. Methods in Medical Research $8: 293-301$

Joyner M J, Lennon R L, Wedel O J, Rose S H, Shephard J T 1990 Blood flow to contracting human muscles: influence of increased sympathetic activity. Journal of Applied Physiology: 1453-1457

Lehmann J F, Warren CG, Scham S M 1974 Therapeutic heat and cold. Clinical Orthopaedics and Related Research 99 : 207-245

LeJemtel Th H, Katz S, Jondeau G, Salomon S 1992 Critical analysis of methods for assessing regional blood flow and their reliability in clinical medicine. CHEST - The Cardiopulmonary Journal $101: 219-222$

Mucha C 1998 Einfluss lokaler Wärmetherapie auf die Unterarmdurchblutung von Patienten mit chronischer Polyarthritis. Physikalische Medizin, Rehabilitationsmedizin, Kurortmedizin $8:$ 71-74

Oka M, Rekonen A, Elomaa I 1971 Muscle blood flow in rheumatoid arthritis. Acta rheumatologica Scandinavica 17 : 203-208

Onabanjo A O 1978 Studies on vasodilatation in the hand on exposure to heat. European Journal of Applied Physiology 38 : 207-213

Peters J K, Vishiyasu T, Mack G W 2000 Reflex control of the cutaneous circulation during passive body core heating in humans. Journal of Applied Physiology 88 : 1756-1764

Rothschild B M, Masi A T 1982 Pathogenesis of rheumatoid arthritis: A vascular hypothesis. Seminars in Arthritis and Rheumatism $12: 11-31$

Silverman D R, Pendleton L 1968 A comparison of the effects of continuous and pulsed short-wave diathermy on peripheral circulation. Archives of Physical Medicine and Rehabilitation 49: 429-436

Skrifvars B, Laine V, Wegelius O 1969 Sclerosis of the arteries of the extremities in rheumatoid arthritis. Acta medica Scandinavica $186: 1445-1472$

Steinbrocker O, Traeger C H, Battermann R C 1949 Therapeutic criteria in rheumatoid arthritis. Journal of the American Medical Association $140: 659-662$

Wessmann H C 1971 Effect of shortwave diathermy to the abdomen on peripheral circulation during pregnancy. Physical Therapy $51: 43-47$ 